\title{
EFL Teachers and English Language Education in the PRC: Are They the Policy Makers?
}

\author{
Minglin Li \\ Griffith University, Australia \\ minglin.li@griffith.edu.au
}

This article explores the relationship between the national English language policy and its implementation at the local level in Chinese schools through the eyes of in-service teachers. Interviews were conducted to examine the policy awareness of EFL teachers in various primary and secondary schools in one province in China. Content analysis was employed to analyze the data to show that EFL teachers were not following the instructions in the national English curriculum to guide their classroom teaching, but were rather critical to the objectives and requirements described in the curriculum. The reason for this was revealed to be the gap between the curriculum policy and practical teaching situations. The results suggested that involving classroom teachers in policy making may help the national language curriculum more applicable and implementable. This may shed light on the question of whether teachers are just implementers or whether they help to shape and develop policy.

Keywords: Actors in language planning, Teacher role, Curriculum implementation, English language education, Language education policy

Previous studies of English language education in the PRC have focused on national policies (e.g., Fu, 1986), on progress and problems in English teaching and learning (e.g., Hu, 2005b), or on the implementation of curriculum policy including the effectiveness of the application of particular teaching methodologies (e.g., Yu, 2001). However, EFL (English as a Foreign Language) teachers' perspectives on educational policies in general, and on the English language curriculum they are required to implement in particular, have been neglected. The extent to which teachers could be involved in policy making for English language education in primary and secondary schools in the PRC has not yet been explored. The examination of these issues forms the focuses of this research.

Language education policy planning in the PRC has been shaped by political, economic and social forces as in many other countries (see e.g., Tollefson \& Tsui, 2004). Given the deep-rooted hierarchical social system in China, the top leaders of the Chinese Communist Party and the Chinese government make decisions and policies for national development on political and economic ends. Following the orientation of the decisions and policies, the MOE (Ministry of Education, which was taken the place by State Education Commission during 1985-1998) organized elites and experts in education to make educational 
policies, including language education policies. These educational policies were then forwarded to the Education Department at Provincial and lower levels for implementation. Under this social-political system in China, people at the lowest level had no say in policy making. English language curriculum development provided a good example in that teachers were only envisioned as implementers of the policies and they did not play a key role in the centralized language planning processes.

It has been shown that since the founding of the PRC in 1949, the political agenda of the time and the socio-economic climate had often motivated the shifts in foreign language educational policies and in the status and role of English as a school subject in China (see e.g., Li, 2007). As Adamson (2004) pointed out that

The English language curriculum has reflected the vagaries of the socio-political climate in China. The curriculum has served as a mechanism for the state to appropriate English to serve its different aspirations, be they revolutionary or economic in orientation. The (often sudden) shifts in state priorities have required curriculum developers to be nimblefooted in ensuring the political correctness of the resources (p. 195).

Prior to 2000, a series of eight English curricula had been designed for students at primary, junior secondary and senior secondary schools in the PRC mainly by the People's Education Press following the educational policies made by the MOE (see Table 1). To meet the needs of the $21^{\text {st }}$ century, experts in curriculum study and linguists in English language teaching and learning, organized by the Department of Basic Education and the National Centre for School Curriculum and Textbook Development of the Ministry of Education, designed the 2001 English curriculum on the basis of the study of theories related to English language education in the areas including general education, language education, curriculum study and course design. Extensive surveys were also conducted on the
English teaching and learning situation in primary and secondary schools in the PRC over the past two decades. An analysis of the 2001 curriculum document indicated that it focuses on the quality of students' overall education through task-based, learner-centred, and communicative language teaching (MOE, 2001).

Teachers in the PRC were "perceived by the government as passive adopters of the official curriculum. Their primary role was to follow faithfully the pre-specified teaching every subject" (Leung, 1991, p. 76). However, some traces of teacher involvement in the English curriculum development, though detailed description was not available, could be found in Adamson (2000), which was shown in Table 1. English classroom teachers had no say in the English curriculum design in 1950s, but since 1960s, some teachers were involved in the development of the curriculum by giving feedback in pilot stage and suggestions.

To explore how the 2001 national English curriculum was interpreted by EFL teachers and implemented in classroom practice, further studies were conducted through the employment of interviews. This study, sited in the broader context of language planning, was to present the findings from the interview data, revealing the actual role EFL teachers were playing in the English curriculum development.

\section{TEACHERS' ROLE IN LANGUAGE PLANNING}

Language planning, as variously defined by scholars in the literature (see e.g., Baldauf, 2006; Cooper, 1989; Rubin \& Jernudd, 1971; Spolsky, 2004; Weinstein, 1980), was broadly perceived as the organized activity to study language issues for solving language problems. The study on the multi-leveled actors in language planning has provided the theoretical context for the present research.

Language planning occurred at a number of levels, and was realized on a continuum at the 


\section{Table 1}

English curricula for primary and secondary schools in the PRC

\begin{tabular}{clll}
\hline Year & Target schools & Policy maker & Teacher involvement \\
\hline 1956 & SS & Central: MOE & Nil \\
1957 & JS & Central: MOE & Nil \\
1963 & JS \& SS & Central: MOE & Feedback \\
1978 & PS, JS \& SS & Central: MOE & Some input to syllabus \& resources \\
1986 & JS \& SS & Central: SEdC & Piloting \& feedback \\
1990 & JS \& SS & Central: SEdC & Piloting \& feedback \\
1992 & PS \& JS & Central: SEdC & Piloting \& feedback \\
1993 & SS & Central: SEdC & Piloting \& feedback \\
& & Central: MOE & $\begin{array}{l}\text { Expanded involvement: repeatedly } \\
\text { consulted and feedback }\end{array}$ \\
2001 & PS, JS \& SS & SS = Senior Secondary School & PS = Primary School \\
\hline $\begin{array}{l}\text { Notes: } \\
\text { JS = Junior Secondary School } \\
\text { MOE = Ministry of Education }\end{array}$ & SEdC = State Education Commission
\end{tabular}

macro, meso and micro levels through a variety of actors. Governmental bodies, agencies (mainly educational agencies) and individuals may be seen to work at different levels in the development and practice of language policy (e.g., Haarmann, 1990; Kaplan \& Baldauf, 1997; Shohamy, 2006; Spolsky, 2004; Van Els, 2005). The language planning process was generally regarded as being top-down, with governments or governmental agencies involving in policy making (Baldauf \& Kaplan, 2003). However, the tendency to consider the impact of local practices had now become one of the dominant paradigms in the area of language policy studies (e.g., Canagarajah, 2005a; Liddicoat \& Baldauf, 2008). In addition, recent moves to install learner-focused language programmes and curricula with an emphasis on life-long learning highlighted this issue. Such programmes made teachers (and their students) responsible for learning. There were a number of researchers who held the belief that classroom teachers are to some extent language planners (e.g. Ashworth, 1985; Freeman, 1996). Ricento and
Hornberger (1996) placed the teachers at the heart of language policy, and claimed that educational and social change and institutional transformation, especially in decentralized societies, often began with the grass roots. Johnson (2009) suggested to empower teachers to become active agents in policy making process. Shohamy (2006) has provided several ways for increasing teachers' involvement in language policies.

Some researchers believed that language policy-related decision making occurred at different levels (e.g., Baldauf \& Ingram, 2003; Cooper 1989; Haarmann, 1990; Kaplan \& Baldauf, 1997; Spolsky 2004). Language planning involved decisions that were taken at both higher and lower levels. "At each level, further policy decisions may arise, depending on how each level reinterprets the original policies" (Bamgbose, 1989, p. 30). A case in point was Markee's comment that "a teacher's decision to use a particular text-book is just as much a policydecision as a Ministry of Education's prescription that English will be taught for X number of hours a 
week in all secondary schools" (as cited in Cooper 1989, p. 38).

For some researchers such as Ashworth (1985), Freeman (1996), and Ricento and Horberger (1996), teachers were primary language policymakers because of their expertise. Freeman (1996) indicated that

Teachers have considerable autonomy in their implementation of high-level decisions, which leaves room for significant variation in the way they put the plan into practice on the classroom level..... considering teachers and administrators as planners allow an understanding of how practitioners potentially shape the language plan from the bottom up (p. 560).

Research on curriculum policy, one policy goal in language education planning (Kaplan \& Baldauf, 2003), explored how official actions are determined, what these actions require of schools and teachers, and how these actions affect what is taught to particular students. Curriculum policy makers were in nature political, and the curriculum policy making process was top-down, with practitioners being the implementers (Elmore \& Sykes, 1992). However, Clandinin and Connelly (1992) held the belief that the teacher was not only expected to be a curriculum implementer, but should be regarded as curriculum maker. Their view of the teacher in relation to curriculum was a view in which the teacher was seen as an integral part of the curriculum, as it was constructed and enacted in the classroom, and in which "teacher, learners, subject matter, and milieu are in dynamic interaction" (Clandinin \& Connelly, 1992, p. 392).

Language teachers, including second/foreign language teachers, played a role in the language curriculum planning process as important as those in general curriculum planning. Much curriculum development appropriately occurred at the classroom level and was, therefore, in the hands of individual teachers throughout the process of curriculum development and that of curriculum implementation (Stern, 1992). The idea that classroom teachers should be given a more active role in all aspects of curriculum renewal such as syllabus design/revision, methodological innovations, implementation, evaluation, and material development had long been a popular theme. Kouraogo (1987) employed two examples, the GLAFL project in Scotland and the Graded Objectives Movement in general, to show how teachers were encouraged to participate in the revision, implementation and evaluation of second-language syllabuses. Woods (1991), when describing a research project carried out with ESL teachers in Canada, suggested that "the teacher plays a far greater role than is generally assumed in the literature in syllabus design and teacher training - in the way by which a language teaching curriculum and the associated teaching materials were interpreted, and in determining the classroom learning experiences that the learners undergo" (p. 2). According to Woods (1991), the teacher was the key player in transforming the conceptual structure into classroom events.

Teachers participated directly or indirectly in the language planning process, but the extent to which they played a role as policy makers was influenced by several interrelated factors: the social-political situation, the educational system, the status quo at local and school levels, self-awareness and self-development. It was hypothesized in this study that in the PRC, English teachers could potentially play a key role in implementing the top-down English language policy, but in addition may have a substantial impact on policy change, thereby indirectly participating in policy making. How English language teachers in the PRC interpreted national language policy and involved themselves in policy making in practice, particularly in curriculum policy planning, was examined as the focus of this research.

\section{PARTICIPANTS AND METHODS}

Eleven groups of 73 in-service EFL teachers from various public schools participated in the 
present study. Three cities in one province in the PRC were selected as the study site for this research, which based on their per capita GDPs, could be respectively argued to be representative of the developed, developing and underdeveloped cities in this part of China. Seven groups of teachers from seven schools were selected in the three selected cities using a stratified random sampling strategy, among which two were primary schools, two were junior secondary schools, two were senior secondary schools, and one was a joint junior and senior secondary school. Two of those schools were located in rural and suburban areas, and five in the centre of the three selected cities.

The researcher was able to secure permission to approach the other four groups of these teachers, who were undertaking teacher training programmes in one of the selected cities, and she interviewed them with their consent. Teachers in the primary school teacher training programme were from different urban, suburban and rural regions in that city, and the secondary school teachers in the other programme were from various places in the selected province.

The semi-structured and focus group interviews were conducted to collect data for the present study. ELF teachers were interviewed either in their offices or in staff meeting rooms in their schools. The participants were asked for permission to have the interviews tape-recorded, or, if there were objections, for note-taking to be used. The questions for the participating teachers covered issues related to 1) their awareness of and knowledge about English language education policy in China and about the 2001 national English curriculum policy, and their concerns about these policies; 2) their involvement in the development of English language education policy for primary and secondary schools in China, and their involvement in the development of the 2001 English curriculum for primary and/or secondary schools in China; and 3) their attitudes towards and perspectives on the EFL teachers' role in English language education policy and national English curriculum policy in China.
Content analysis was employed both quantitatively and qualitatively during the analytical procedure where Miles and Huberman's (1994) flow model was used for analyzing interview data. The results of the quantitative content analysis were presented as frequency counts of "theme" - the basic unit used in the present study; while the results of the qualitative content analysis could be presented as illustrative quotations (Wilkinson, 2004). To identify the quotes, codes (i.e., TP, TJ, TS and TJS) were created, where TP1 to TP11 were for primary school teachers, TJ1 to TJ31were for teachers from the junior secondary schools, TS1 to TS16 were for teachers from the senior secondary schools, and TJS1 to TJS15 were for teachers in the joint junior and senior secondary schools.

For the purpose of clearer presentation, the results would be discussed under five thematic topics based on the number of their mentions in a descending order. The interview findings were to be summarized, but only illustrative quotations were to be presented. Themes which emerged from the interviews but were not related to this study were not discussed nor presented.

Limitations may exist during the process of data collection. When choosing in-service EFL teacher participants for the interviews, no specific criteria were used for participant selection. The teachers who had been working in the selected primary and secondary schools, and who agreed to participate in the research were interviewed. Such sampling did not lend itself to the analysis of findings based on variables like age, gender, or previous education.

\section{FINDINGS}

\section{Teachers' role in educational policy development}

The issue of teachers' role in English language education policy has caused many hesitations to occur in conversations. Nevertheless some issues were raised by the EFL teachers interviewed, showing the actual roles that teachers have been 
playing, as well as their attitudes towards this issue.

All the teachers interviewed reported that there were no opportunities at all to participate in policy making relating to English language education in primary and secondary schools. The word "policy" for them was synonymous with the decisions made by leaders at higher levels, and the teachers were merely implementers. The following comment by a teacher was rather common among all groups of the interviewees: "Policies were made by leaders. Somebody came and explained them to us, that's all. In regard to the policy making process, we are not supposed to be involved in it" (TS6).

However, most of the teachers stated that they definitely wanted to be involved in policy making in areas such as curriculum design, constructing and selecting teaching materials, and methodology. In this role they would at least be able to provide data from their actual situation in regular schools as inputs to policy - data which they believed the experts needed as a basis for their policy making activities, which in turn could meet the needs of the majority of students in China if it were to become national policy. However, the reality was that none of the EFL teachers interviewed had participated in the curriculum policy making process, and few were consulted in the selection of the prescribed teaching materials for schools in their regions. One teacher reported participating once in compiling supplementary exercises for testing skills for students in this province.

A few teachers said that from time to time they had intended to talk to higher-level leaders about their opinions or suggestions related to their teaching and students' learning, or about educational policy related issues, but as they said "nobody would be approachable, and I'm afraid my suggestions will not be accepted" (TS15). "It's extremely hard to find a suitable person to talk to about these things. Those people who are in the area of English education and at the same time have the power won't sit here listening to us" (TJS7). "All the policies are right because they are made by leaders. If you say they are wrong, then
I think that's the end of your teaching journey!" (TS8). Due to these beliefs, teachers had gradually become indifferent to issues related to national English education policy.

Three teachers in two groups said they had never thought about participation in policy-making activities. They were used to working under the supervision of their leaders, doing whatever they were told to do. "English is required to start in primary school. They told us to offer it, then just do it" (TS13). "To be a policy maker? I'm afraid I'm not capable in doing that" (TJS4).

All the EFL teachers interviewed reported that they were only policy implementers. However, this was not entirely the case, as they had to some extent made their own decisions in classroom teaching, as the following quotes illustrate. "When we find that the new curriculum is not practical in classroom teaching, but there is no way to let policy makers know about our opinion, we just ignore the instructions in it. We just follow those we think suitable" (TS9). "The methodologies suggested in the curriculum sound good, but we use our way according to the students' needs and their individual differences" (TJS7). "There is too much material in the textbooks for us to finish, we have to delete some though it is hard to do so" (TS15). "We select something else from newspapers or published exercise collections for enhancing students' knowledge and training their testing skills" (TJS8).

\section{Actors in educational policy development}

For the EFL teachers who were interviewed, actors involved in educational policy development were policy makers and policy implementers. The respondents considered teachers to be only policy implementers, although many of them thought they should be part of the actor pool in educational policy development, and they wanted to play a role in the policy making process. The following results showed, with the exception of two mentions indicating that they had no idea who the actors were, that two groups of people were regarded as the policy makers: "the leaders" or "those people", and "the experts". 
"The leaders" or "those people" were terms used by the teachers to refer to the senior policy staff and administrators working in government or educational sections of the government at the state level, or to some extent at the provincial level, who could be involved in formulating educational policies. It was pointed out that "The local educational bureau couldn't have a say, nor could the grass roots" (TJ17). "However, the leaders may not know how English should be learned, neither do they know about the actual local situation in most of the regions" (TS2).

"The experts" referred to those people who had been called together to design the English curriculum and to compile the textbooks. The respondents had a similar opinion of "the experts" as they did of "the leaders". The respondents claimed that "The experts may have a good understanding of how the English curriculum should be designed in Western countries, but they had no idea about how English has been taught and learned in most Chinese schools" (TS14). "That's why we think that the new English curriculum is just ivory-towered" (TJS1). A teacher described "the experts" in the following way:

Teaching materials cannot be beyond the receptivity of the students. Textbook compiling should be based on the actual capability of the students. Now you see, there's no connection at all between the experts compiling textbooks and implementers using the textbooks. We are people in two different worlds! Classroom teachers should be involved in textbook compiling, but no, the experts did it just because they are experts even though they know nothing about the learning situation. The experts are not teaching, people who are teaching are not experts! We are just people from two worlds!" (TS2).

Prestigious secondary school teachers were mentioned twice as possibly being involved in policy making. "If teachers were consulted in the making of policies, well-known teachers but not ordinary ones could have been appointed by local educational bureau" (TJS3).

\section{Educational system in China}

Another important issue the interviewees raised was related to the educational reforms in China in the recent two decades. It focused on two orientations in basic education: examination and quality-education.

It was reported that the examination, but not quality-orientated educational system, remained unchanged. The foremost priority of both teachers and students was to get higher marks in the entrance examinations in order to secure positions in universities because positions at tertiary level were limited. "Students" marks" and "teaching for examinations" were mentioned most frequently during the interviews by EFL teachers. Teachers did not want to risk trying the teaching methods recommended in the 2001 English curriculum, which were in line with the recent international trends in second language teaching, but rather stuck to the experience-proven grammar-translation approach. This was because they wanted to help students to get high marks in examinations, but did not want to be "losers" (used by TS3) and disappoint students and their parents.

The idea of quality-oriented education was reported by teachers to be good for students' overall development, but the teachers pointed out that it was not at all practical to carry out the reform for quality education under the current testing system. Because of the demands of quality education, more time would have to be spent on learning materials other than what was included in their textbooks for overall quality improvement. This could explain why students, as well as teachers, became more and more tired. One teacher said that "It was OK before the reform, but now students have very great pressure!" (TJ26). A teacher in another school complained that:

Educational reform is to lighten students' load, but what was said in policy documents is far away from what has occurred in practice. Actually, every subject has caused a heavier load to students because of richer information in textbooks. The new curriculum and new textbooks should be helpful with students' 
overall development, but it is not equally helpful with lightening the students' load. Qualityoriented education has in fact increased the pressure on students (TS12).

\section{New English curriculum}

The 2001 English curriculum was reported to have been implemented since 2003 or 2004 in different cities. The EFL teachers mentioned most frequently the ideal but not practical objectives described in the curriculum, together with teaching materials, which to them defined the curriculum.

Most of the teachers interviewed knew about the curriculum policy document, through a very brief reading or by taking training programmes. They claimed that the curriculum was well designed, and the goals and objectives described in it were academically viable, but that these goals and objectives were too ideal to be realized in practical teaching in China: "They are not realistic at all!" (Many teachers' comments). Teachers in one school explained how those goals and objectives played out in practice:

The objectives - described in the 2001 English curriculum - are in line with the general goals for our national course reform. Big-wigs in each subject area were called together and were required to design the objectives for each subject on the basis of the general goals - Three Dimension Goals (San Wei Mubiao)! The first is about knowledge, the second is about process and methodology, and the third is about affective attitude and value embodiment. Whatever the subject, these 'Three Dimensions' would have to be followed!

Personally I don't think those people who have designed the English curriculum really knew about the actual English teaching and learning situation in China! They had no idea (about the actual situation)! That's why they've put forward objectives beyond students' capabilities! (TJS1).

Similar opinions were heard frequently from teachers interviewed in other schools, such as
"When we say the objectives are too demanding we mean that they are not suitable for most of the students" (TS14). "They may be OK with students in top schools in big cities" (TJ4). "They are not practical at all. We suggest those experts designing the curriculum and compiling the textbooks teach a few lessons to students in lower level schools (schools expect top ones in big cities). This is discrimination against those schools in rural areas!" (TJS10).

In spite of all the comments on the objectives described in the curriculum, some teachers mentioned that they knew little about the ideas presented in it. "We've got some materials related to the new curriculum when taking training programmes, but who reads them?!" (TS8). "In classroom teaching, we just follow the requirements of our immediate superiors, but not the instructions in the curriculum" (TP9). Teachers in one school said they knew nothing about the ideas and recommendations in the 2001 curriculum because they did not even have the curriculum document, nor had they had any training in implementing it. For them, the new textbook was the new curriculum.

Another story also showed that some teachers were not familiar with the curriculum itself, nor with the theories related to language teaching. One group of teachers when talking about the methods they were using said: "We all know how to use the methods suggested in the curriculum. Studentcentred teaching is adopted, that's for sure". They then described what student-centredness meant in their school:

As when doing written exercises, answering teachers' questions, or when asked to express themselves, students are regarded as the centre. You know, teacher lecturing is the most important, but student practice is also necessary. Student-centredness basically means doing exercises. There are some communicative exercises, and some listening exercises.

Whatever knowledge teachers had about the 2001 English curriculum, many teachers reported that "it was perfectly designed but is 
very difficult to carry out" because "curriculum or not, the purpose of teaching and learning is for the students to pass the examinations" rather than for achieving the objectives set out in the curriculum (TJ16).

\section{Administrative system in China}

There were four mentions relating to the administrative system in China, specifically concerning the relationship between superiors and the inferiors. The inferiors were supposed to obey the superiors at all times. Two examples were given by teachers from two groups:

Those leaders have never come to see what the actual teaching and learning situation is like. What they do is to inform us that people (leaders) at provincial level or local level will come to our school to inspect this or that. Then we'll have to prepare some stuff they want to see, showing what we have done, whether or not we have done so. This is what is happening everywhere, fiddling with the facts and then reporting to the higher-level leaders. We don't think they really know the actual situation. If they really want to know, just come, it's not necessary for us to prepare that stuff, not necessary to come as a leader! (TJS14).

Leaders, or the policy makers, can never get the truth under the power-centred system in China at present! They may occasionally want to know what is happening at the local level. Then they would tell people at the lower level to come for their reports. There are always those people who will think hard about what the leaders would like to hear. They just report what those leaders like. Just sing songs of praise! If you don't praise the leader, he would think you are being against him. The same happens in education, in teaching. What is disastrous is that experts come and get to know the reality, hear all voices from the teachers, but when they make the reports they would have to consider how their immediate leaders, or leaders at a higher level or top level, would evaluate them (the experts)! (TJS1).

\section{DISCUSSION AND CONCLUSION}

Based on data gathered from the in-service EFL teachers, this study provides evidence that China's national language education policy for English curriculum, which has been designed around a centralized approach with teachers being simply implementers, is at this point in time to a large extent only a document for reading, but not for implementing. It is reported by the teachers that the curriculum is well designed on the theoretical side, but the objectives and requirements of teachers in the curriculum are set too high by the experts who had little knowledge about what is actually happening in most of the English classrooms in Chinese schools, and are difficult for classroom teachers to attain. Furthermore, the unchanged examination-oriented educational system makes it even harder for teachers to follow the instructions in the curriculum. The English curriculum as a policy document has not in practice functioned as it should in teachers' classroom teaching. This is common for the policies to be unsuccessfully implemented if they fail to consider the specific challenges that teachers confront in their teaching practice (Tollefson, 2002; see e.g., Hu, 2002; Li, 1998; Li \& Baldauf, 2010; and Nunan 2003, for similar examples).

Language teachers can be said to regard themselves as practical people and not as theorists. For some teachers, theory is an unattainable ideal or a set of postulates which are not applicable in the harsh world of reality (Stern, 1983, p. 23). In addition, individual teachers may have their own beliefs and not see the pedagogical implications or follow the specifications contained in the curriculum guides, or may not even accept the theoretical paradigm around which they are constructed (Doyle, 1992). This has been proven by the findings from this study. In their teaching practice, EFL teachers are actually decision makers instead of curriculum implementers. They seldom follow the instructions and recommendations in the English curriculum, but teach in the way that they thought to be better for their students' examination results 
(see e.g., the quotations of the interviewees TS9 and TJS7).

The other major reason for the failure in implementing the new English curriculum has been acutely pointed out to be that the lack of classroom teachers' involvement in the curriculum development has broadened the gap between the theory/policy and practice. EFL teachers, according to different researchers discussed previously, have various roles in the development of language education policy and curriculum policy, but in the framework of the present study, EFL teachers are deemed to be purely implementers of the English curriculum policy. Except for a few prestigious EFL teachers who might have been consulted, most have no say in any policy making process concerning English language education in China; they are not involved in curriculum design nor in teachingmaterials selection. Although they believe they can help policy makers by giving informative suggestions, their long-standing role as just policy implementers has provided no opportunity for them to be involved in policy making.

"Implementation involves a change in beliefs and this usually can only come about through personal involvement in the innovation" (Brindley \& Hood, 1990, p. 241). The realization of the contextual influence can empower local teachers to focus on the learning strategies that work for their own students in the light of the purposes and objectives that define their teaching (Canagarajah, 2005b, p. xxviii), but prescribing for teachers what and how to teach reflects a top-down view of teaching and marginalizes the role of teachers and context (Hu, 2005a). In the PRC, the testing system, different national policy goals from those of individuals, and the inconsistency between policy and practice have caused great difficulty in successfully implementing the new national English curriculum. Teachers' practice and experience can provide contextual evidence for curriculum developers to consider when reforming the curriculum, changing armchair policy into policy suitable for implementation. As Brindley and Hood (1990) point out, "a better understanding of how curriculum implementation happens 'on the ground' ... would help to put language curriculum development on a more rational footing and allow curriculum developers to plan more effectively for the changes that follow innovation" (p.233). In this sense, classroom teachers have a role to play as curriculum policy makers.

However, although the data from this study show that EFL teachers are rather critical of the goals and requirements suggested in the new national English curriculum, they have made little effort to influence the policy making process but have become indifferent to policies related to their teaching due to their lowly position, where they have no say in educational policy making, and their priority for students to attain high marks in examinations. This indifference has become inimical to not only the curriculum reform but also will be to any educational reforms. The consequence of this indifference can be seen from the results of this study which reveals the fact that inaccurate information has been obtained from lower levels which might have misled the decisions of policy makers. Given the power-centred hierarchical socio-political system in the PRC, people can sometimes face the risk of losing their jobs if they do not obey their superiors (see e.g., the quotation from TS8). While there has been more democracy in the PRC since China started the Open Door policy, and while China has become more internationalized and globalized in its political, economic and educational systems with series of reforms, it is still difficult to practise actual democratic critique in the Chinese context. This means that most people do not feel able to provide their superiors with negative comments on policies originating at higher levels. What is even worse is that some people fabricate information just to please their superiors (see e.g., the quotation from TJS14). The same can be said of English education in primary and secondary schools in China. Classroom EFL teachers have examination marks as their priority, which is different from the English curriculum objectives. They follow the instructions in the 
curriculum in writing teaching plans, which may be inspected by their educational inspectors, and teach for examinations (Li \& Baldauf, 2010). Teachers try to follow the English curriculum (for example, communicative language teaching methods) in specially prepared classes presented to experts or leaders when they come to schools for inspections or to conduct surveys, or presented as a model class for teachers from other schools, but most of the time teachers and students are still learning English in the traditional way (mostly by grammar translation). On the whole, teachers are not implementing the new English curriculum, but instead use the new textbooks to teach traditionally. Policy makers sometimes receive only fabricated information about what is actually going on in English classrooms in schools.

This lack of faith in the well-designed English curriculum plus the pretension in policy implementation and false information for leaders and superiors may suggest that having teachers to play a key role in curriculum development or educational policy making seems unlikely to occur in the near future in the Chinese context, although the Chinese government has started to encourage classroom teachers to become involved in the process of national educational policy making. I argue that teachers themselves need to try to develop a more democratic environment, and to place more trust in and show support for the government. To do this, teachers need enthusiasm to make progress professionally and to volunteer to contribute to educational reforms. Only when classroom teachers themselves are ready to be at the heart of language policy (Ricento \& Hornberger, 1996) is educational reform likely to be successful.

The findings from the present research also suggest that the extent to which the policies can be implemented, and the actual needs and contextual situations of the policy target groups, have not been properly assessed by policy makers. This makes the implementation of the policy difficult or even impossible. This may imply that educational policy making, as with policy making in other areas in the Chinese context, is characterized to some extent by meeting idealised bureaucratic needs. Such people make policies which they believe to be good for the country, for the people and for their careers as leaders, but often the policies are just "an outcome of power struggles" (Tollefson, 1995, p. 2), and their power-centred ideology has led them to neglect valuable input from lower level policy practitioners or fail to judge the validity and reliability of the information if they actually do the research. To make it less likely and make the policies more implementable, policy makers will face a major challenge in the future of how to provide a more open system by effectively involving classroom teachers in the educational policy making process. This also has the implication to the social system in that empowering teachers in language policy making may make them feel the equality as individuals of the community and society, and thus encourage them to undertake the responsibility and actively participate in the construction of language education policies.

\section{REFERENCES}

Adamson, B. (2000). China's official English: The curriculum for junior secondary schools since 1949. Retrieved from www.hltmag.co.uk/ may03/martmay031.rtf.

Adamson, B. (2004). China's English: A history of English in Chinese education. Hong Kong: Hong Kong University Press.

Ashworth, M. (1985). Beyond methodology: Second language teaching and the community. Cambridge, UK: Cambridge University Press.

Baldauf, R. B., Jr. (2006). Rearticulating the case for micro language planning in a language ecology context. Current Issues in Language Planning, 7 (2\&3), 147-170.

Baldauf, R. B., Jr., \& Ingram, D. (2003). Languagein-education planning. In W. J. Frawley (Ed.), International encyclopedia of linguistics $\left(2^{\text {nd }}\right.$ ed.) (Vol. 2, pp. 412-416). Oxford, UK: Oxford University Press. 
Baldauf, R. B., Jr., \& Kaplan, R. B. (2003). Language policy decisions and power: Who are the actors? In P. Ryan \& R. Terborg (Eds.), Language: Issues of inequality (pp. 19-40). Mexico City: Universidad Nacional Autonoma de Mexico.

Bamgbose, A. (1989). Issues for a model of language planning. Language Problems and Language Planning, 13 (1), 24-34.

Brindley, G. \& Hood, S. (1990). Curriculum innovation in adult ESL. In G. Brindley (Ed.), The second language curriculum in action (pp. 232-248). Sydney, Australia: National Centre for English Language Teaching and Research, Macquarie University.

Canagarajah, S. A. (2005a). Accommodating tensions in language-in-education policies: An afterword. In A. M. Y. Lin \& P. W. Martin (Eds.), Decolonisation, globalisation: Language-in-education policy and practice (pp. 194-201). Clevedon, UK: Multilingual Matters Ltd.

Canagarajah, S. A. (2005b). Introduction. In S. A. Canagarajah (Ed.), Reclaiming the local in language policy and practice (pp. xiii-xxx). Mahwah, N. J.: Erlbaum.

Clandinin, D. J., \& Connelly, F. M. (1992). Teacher as curriculum maker. In P. W. Jackson (Ed.), Handbook of research on curriculum: A project of the American Educational Research Association (pp. 363-401). NY: Macmillan.

Cooper, R. L. (1989). Language planning and social change. Cambridge, UK: Cambridge University Press.

Doyle, W. (1992). Curriculum and pedagogy. In P. W. Jackson (Ed.), Handbook of research on curriculum: A project of the American educational research association (pp. 486516). NY: Macmillan.

Elmore, R., \& Sykes, G. (1992). Curriculum policy. In P. W. Jackson (Ed.), Handbook of research on curriculum: A project of the American Educational Research Association (pp. 185-215). NY: Macmillan.

Freeman, R. D. (1996). Dual-language planning at Oyster Bilingual School: "It's much more than language". TESOL Quarterly, 30 (3), 557-582.

$\mathrm{Fu}, \mathrm{K}$. (1986). Zhongguo waiyu jiaoyu shi $[A$ history offoreign-language teaching in China]. Shanghai, China: Shanghai Foreign Language Education Press.

Haarmann, H. (1990). Language planning in the light of a general theory of language: A methodological framework. International Journal of the Sociology, 86, 103-126.

$\mathrm{Hu}, \mathrm{G}$. (2002). Potential cultural resistance to pedagogical imports: The case of communicative language teaching in China. Language, Culture and Curriculum, 15 (2), 93-105.

$\mathrm{Hu}, \mathrm{G} .(2005 \mathrm{a})$. Contextual influences on instructional practices: A Chinese case for an ecological approach to ELT. TESOL Quarterly, 39 (4), 635-660.

$\mathrm{Hu}, \mathrm{G}$. (2005b). English language education in China: Policies, progress, and problems. Language Policy, 4 (1), 5-24.

Johnson, D. C. (2009). The relationship between applied linguistic research and language policy for bilingual education. Applied Linguistics, 31 (1), 72-93.

Kaplan, R. B., \& Baldauf, R. B., Jr. (1997). Language planning: From practice to theory. PA: Multilingual Matters.

Kaplan, R. B., \& Baldauf, R. B., Jr. (2003). Language and language-in-education planning in the Pacific Basin. Dordrecht, The Netherlands: Kluwer Academic.

Kouraogo, P. (1987). Curriculum renewal and INSET in difficult circumstances. ELT Journal, 41 (3), 171-178.

Leung, Y. J. (1991). Curriculum development in the People's Republic of China. In C. Marsh, \& P. Morris (Eds.), Curriculum development in East Asia (pp. 61-81). London, UK: Falmer Press.

Li, D. (1998). "It's always more difficult than you plan and imagine": Teachers' perceived difficulties in introducing the communicative approach in South Korea. TESOL Quarterly, 32 (4), 677-703. 
Li, M. (2007). Foreign language education in primary schools in the People's Republic of China. Current Issues in Language Planning, 8 (2), 148-161.

Li, M., and Baldauf, R. B., Jr. (2010). Beyond the curriculum: Issues constraining effective English language teaching: A Chinese example. TESOL Quarterly, 44, in press.

Liddicoat, A. J., \& Baldauf, R. B., Jr. (Eds.) (2008). Language planning in local contexts. Clevedon, UK: Multilingual Matters.

Miles, M. B., \& Huberman, A. M. (1994). Qualitative data analysis: An expanded sourcebook (2 $2^{\text {nd }}$ ed.). Thousand Oaks, CA: Sage.

MOE (Ministry of Education) (2001). Quanrizhi yiwu jiaoyu putong gaoji zhongxue yingyu kecheng biaozhun (shiyangao) [English curriculum for compulsory education and senior secondary education (Trial)]. Beijing, China: Ministry of Education, Peoples' Republic of China.

Nunan, D. (2003). The impact of English as a global language on educational policies and practices in the Asia-Pacific region. TESOL Quarterly, 37 (4), 589-613.

Ricento, T. K., \& Hornberger, N. H. (1996). Unpeeling the onion: Language planning and policy and the ELT Professional. TESOL Quarterly, 30 (3), 401-427.

Rubin, J., \& Jernudd, B. H. (1971). Introduction: Language planning as an element in modernization. In J. Rubin, \& B. H. Jernudd (Eds.), Can language be planned? Sociolinguistic theory and practice for developing nations (pp. xiii-xxiv). Honolulu, HI: The University Press of Hawaii.

Shohamy, E. (2006). Language policy: Hidden agendas and new approaches. London, UK: Routledge.
Spolsky, B. (2004). Language policy. NY: Cambridge University Press.

Stern, H. H. (1983). Fundamental concepts of language teaching. Oxford, UK: Oxford University Press.

Stern, H. H. (1992). Issues and options in language teaching. Oxford, UK: Oxford University Press.

Tollefson, J. W. (1995). Introduction: Language policy, power, and inequality. In J. W. Tollefson (Ed.), Power and inequality in language education (pp. 1-8). Cambridge, UK: Cambridge University Press.

Tollefson, J. W. (2002). Conclusion: Looking outward. In J. W. Tollefson (Ed.), Language policies in education: Critical issues (pp. 327337). Mahwah, NJ: Lawence Erlbaum.

Tollefson, J. W. \& Tsui, A. B. M. (2004). Medium of instruction policies: Which agenda? Whose agenda? Mahwah, NJ: Erlbaum.

Van Els, T. (2005). Status planning for learning and teaching. In E. Hinkel (Ed.), Handbook of research in second language teaching and learning (pp. 971-991). Mahwah, NJ: Erlbaum.

Weinstein, B. (1980). Language planning in francophone Africa. Language Problems and Language Planning, 4 (1), 55-77.

Wilkinson, S. (2004). Focus group research. In D. Silverman (Ed.), Qualitative research: Theory, method and practice (2 ${ }^{\text {nd }}$ ed.) (pp. 177-199). London, UK: Sage.

Woods, D. (1991). Teachers' interpretations of second language teaching curricula. RELC Journal, 22 (2), 1-18.

Yu, L. (2001). Communicative language teaching in China: Progress and resistance. TESOL Quarterly, 35 (1), 194-198. 